Article

\title{
Sulfur isotopic ratios and mode of occurrence of stibnite at the Hishikari epithermal Au-Ag deposit, Japan
}

\begin{abstract}
Toru Shimizu, ${ }^{1, *}$
Toru Shimizu (2017) Sulfur isotopic ratios and mode of occurrence of stibnite at the Hishikari epithermal Au-Ag deposit, Japan. Bull. Geol. Surv. Japan, vol. 68 (3), p. 111-117, 5 figs, 1 table.

Abstract: Mode of occurrence and sulfur isotopic ratios $\left(\delta^{34} \mathrm{~S}\right)$ of stibnite were investigated to understand the characteristics of stibnite mineralization, and the source of stibnite sulfur at the Hishikari epithermal $\mathrm{Au}-\mathrm{Ag}$ deposit. Stibnite occurs as prismatic or acicular crystals forming radiating aggregates in quartz druses, indicating that stibnite precipitated during the last stage of sequential mineralization.

Stibnite samples were collected from several veins at 40 and $10 \mathrm{ML}$ (mine meter level) within the bonanza (high-grade $\mathrm{Au}$ ) zone, located between 150 and $-50 \mathrm{ML}$. Sulfur isotopic values $\left(\delta^{34} \mathrm{~S}\right)$ of stibnite samples yielded a narrow range: -0.2 to $+0.7 \% 0(\mathrm{n}=7)$, and are similar to previous $\delta^{34} \mathrm{~S}$ data from ginguro (an Au-Ag-rich black sulfide band) in earlier mineralization ( +0.4 to $+0.6 \% 0)$, and to $\delta^{34} \mathrm{~S}$ data from pyrite in veins and hydrothermally-altered host rocks (Shimanto Supergroup sedimentary rocks)(-1.1 to $+1.8 \%$ ).

The presence of stibnite within the bonanza zone indicates that stibnite mineralization overprinted Au$\mathrm{Ag}$ mineralization at the same depth. Considering that stibnite commonly forms in the peripheral portions of the epithermal environment, e.g., stibnite deposition on the top of an Au-Ag orebody near the surface, the overprinting of stibnite mineralization on $\mathrm{Au}-\mathrm{Ag}$ mineralization at depth in the Hishikari deposit may reflect mineralogically exceptional circumstances.

The narrow isotopic range of stibnite sulfur could be due to a spatially homogeneous source of stibnite sulfur. The isotopic similarity between stibnite and ginguro sulfur suggests that the source of sulfide sulfur may have been the same throughout both early and late vein formation. The similarity between sulfur isotopic values in stibnite and other sulfides (ginguro and pyrite) also suggests that the source of stibnite sulfur is likely to be dominantly magmatic, as with the source of other sulfide sulfur discussed in previous studies of this deposit.
\end{abstract}

Keywords: stibnite, sulfur isotopes, mode of occurrence, Hishikari deposit

\section{Introduction}

Stibnite $\left(\mathrm{Sb}_{2} \mathrm{~S}_{3}\right)$, a principal source of mined antimony $(\mathrm{Sb})$, is a common vein mineral in hydrothermal systems (Schwarz-Schampera, 2014). Although stibnite is one of the common accessory minerals at the Hishikari epithermal Au-Ag deposit (Sekine et al., 2002), studies of its genetics are scarce.

Sulfur isotope data for stibnite are a powerful tool for understanding the genesis of stibnite mineralization, in conjunction with other geological, mineralogical, and geochemical data (e.g., Robinson and Farrand, 1982; Gokçe and Spiro, 1991; Ishihara et al., 2000; Imai et al., 2006). However, sulfur isotopic values for stibnite at the Hishikari deposit have not been previously documented, except for one value of $-0.2 \%$ reported by Imai et al. (2006); this was not fully discussed in terms of the source of stibnite sulfur.

This study presents the morphological modes of occurrence for stibnite crystals, and their sulfur isotopic values from several veins. It discusses the spatial characteristics of stibnite occurrence, and the potential source of stibnite sulfur in comparison to previous isotopic data from other sulfides at the Hishikari deposit.

\section{Geologic background and mineralization}

The Hishikari deposit is located in southern Kyushu, Japan (Fig. 1a). Other Au-Ag deposits near Hishikari include Okuchi, Yamagano, Kushikino, Akeshi and Kasuga. The Hishikari deposit formed in the Pleistocene (0.61-1.25 Ma) (Izawa et al., 1993; Sanematsu et al., 2005; Tohma et al., 2010), within basement sedimentary rocks of the Cretaceous Shimanto Supergroup and

\footnotetext{
${ }^{1}$ AIST, Geological Survey of Japan, Research Institute of Earthquake and Volcano Geology

${ }^{*}$ Corresponding author: T. Shimizu,Central 7,1-1-1 Higashi, Tsukuba, Ibaraki 305-8567, Japan. Email: t.shimizu@aist.go.jp
} 


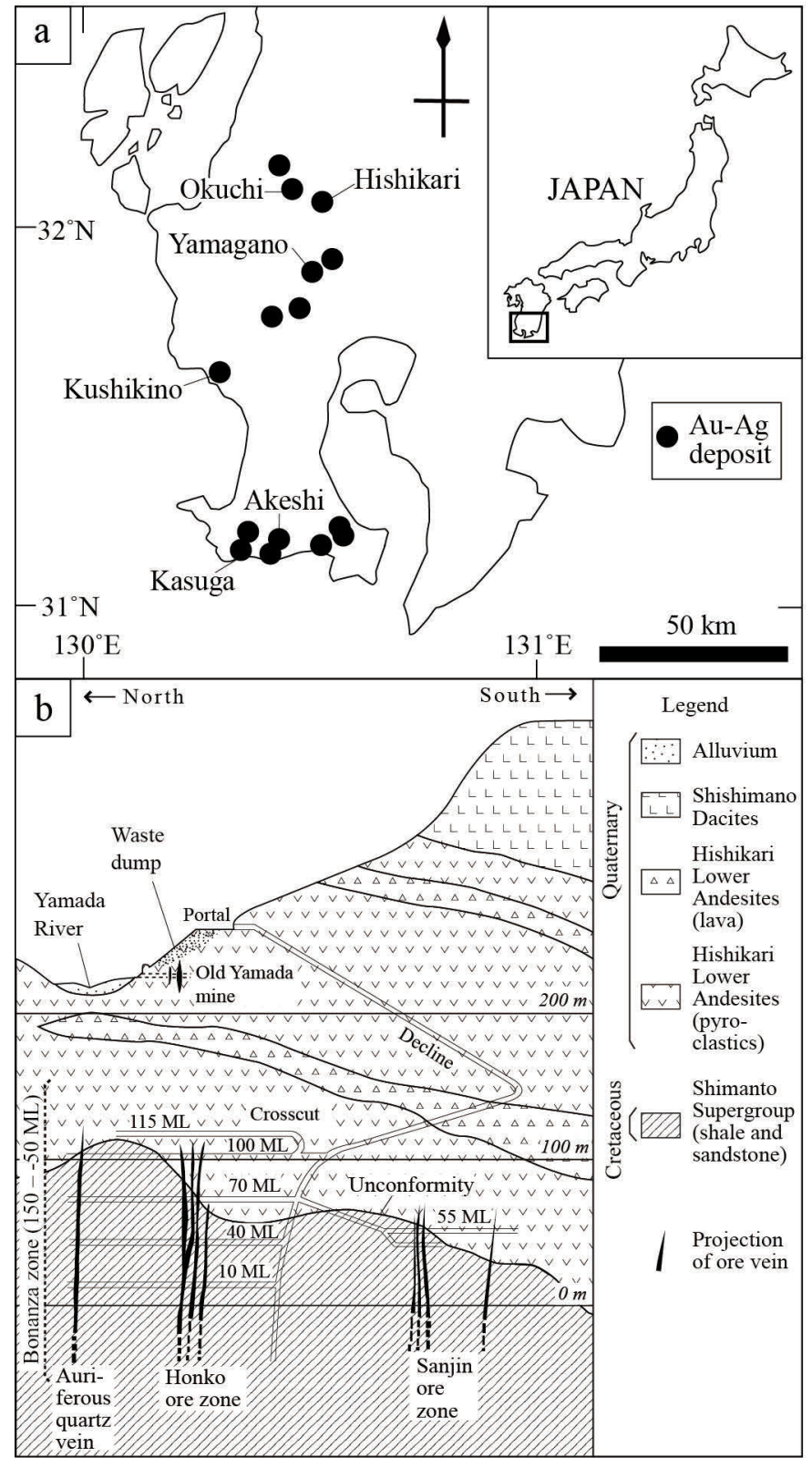

Quaternary volcanic rocks in ascending order (Fig. 1b). The deposit consists of three ore zones: Honko (Main), Sanjin, and Yamada (Fig. 2); the Honko and Sanjin zones are relatively enriched in $\mathrm{Au}$, especially in the upper half of the ore zones (Ibaraki, 1990; Ibaraki and Suzuki, 1993). In these ore zones, quartz veins generally strike $\mathrm{N} 50^{\circ} \mathrm{E}$ and dip 70-90 ${ }^{\circ} \mathrm{NW}$ (Izawa et al., 1990). Drill core surveys show that the high-grade Au "bonanza" zone is located between 150 and -50 ML (mine meter level, which is equal to above sea level, Fig. 1), although low-grade Au veins continue at depth (Ibaraki and Suzuki, 1993). Ore veins are classified as early and late veins based on observed vein crosscutting relationships (Sekine et al., 2002).

The assemblages of ore and gangue minerals are the same for early and late veins (Sekine et al., 2002). Ore minerals mainly consist of electrum, chalcopyrite, pyrite,
Fig. 1 Location (a) and schematic geological cross section around the Honko and Sanjin ore zones at the Hishikari deposit (b) (Partly modified after Sekine et al., 2002). 'ML' denotes the mine meter level. Meter ( $\mathrm{m})$ in italics indicates elevation above sea level. Some ore veins, not shown in the figure, continue up to $150 \mathrm{ML}$ (Ibaraki and Suzuki, 1993).

and marcasite, with minor constituents of naumannite, sphalerite, galena and stibnite. The gangue minerals are mainly quartz, adularia, smectite with small amounts of sericite, chlorite, and kaolinite. Ginguro (an Au-Ag-rich black sulfide band, "silver black") tends to be present along the outer side of early veins in higher levels of the deposits (Izawa et al., 1990; Sekine et al., 2002). Izawa et al. (1990) reported that antimony was first deposited as pyrargyrite $\left(\mathrm{Ag}_{3} \mathrm{SbS}_{3}\right)$ and miagyrite $\left(\mathrm{Ag}_{2} \mathrm{Sb}_{2} \mathrm{~S}_{4}\right)$ in the ginguro, then as stibnite and pyrargyrite with fine-grained pyrite in cracks, druses and fractures in the veins. Finegrained anhedral quartz is commonly associated with adularia, forming porcellanous white bands, as shown in the Ryosen vein swarm in the Honko zone; these were subsequently overprinted by euhedral quartz, forming druses (Matsuhisa and Aoki, 1994; Shimizu, 2015). 


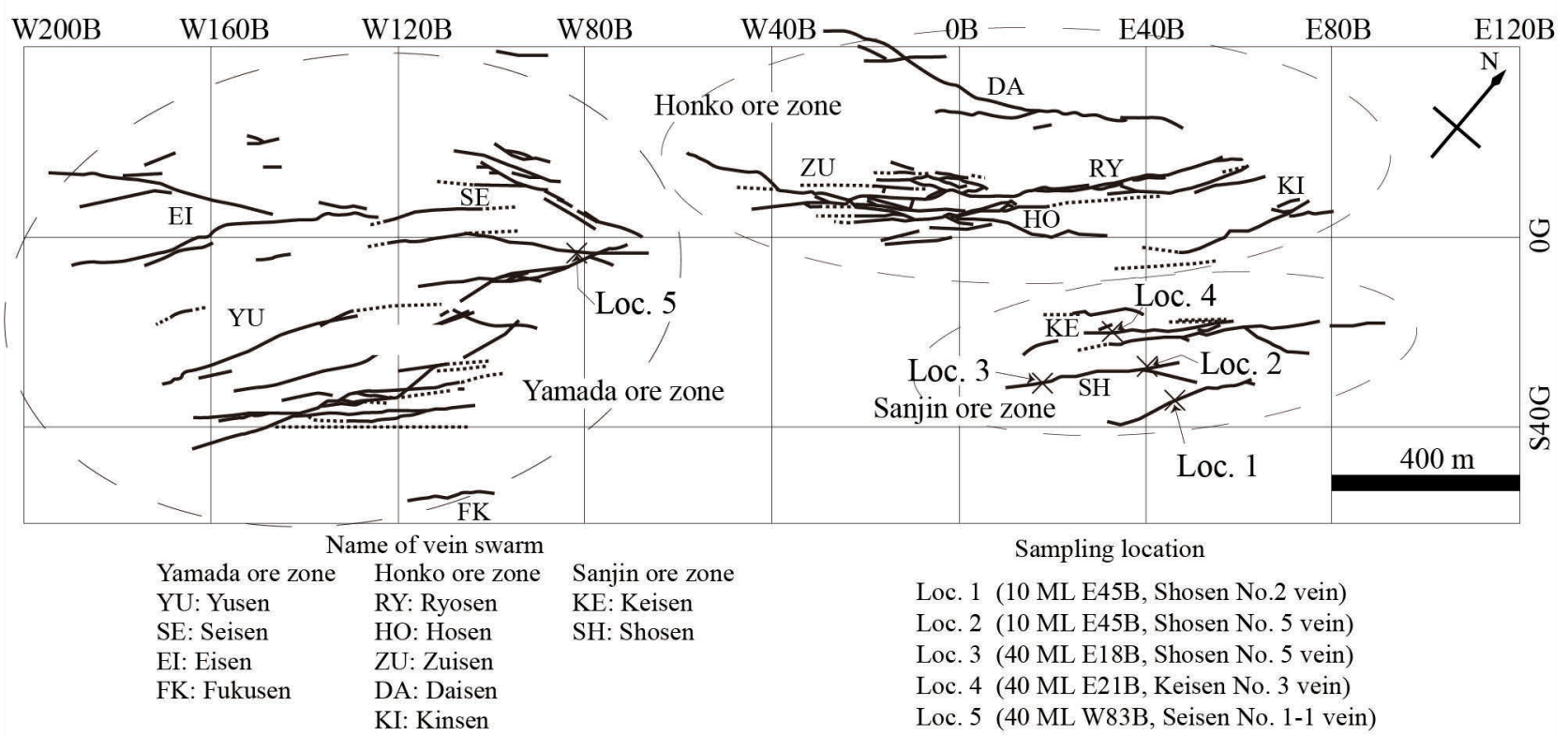

Fig. 2 Sampling location plotted on the vein map of the Hishikari deposit (Sumitomo metal Mining Co., Ltd., 2012). The vein distribution is projected to $40 \mathrm{ML}$ ( $40 \mathrm{~m}$ mine level $=40 \mathrm{~m}$ above sea level).

\section{Methods}

Sample collection and observation

Samples were collected from five locations among different veins, at different mine levels: Loc. 1 (10 ML, Shosen No. 2 vein), Loc. 2 (10 ML, Shosen No. 5 vein), Loc. 3 (40 ML, Shosen No. 5 vein), and Loc. 4 (40 ML, Keisen No. 3 vein) in the Sanjin ore zone, and Loc. 5 (40 ML, Seisen No. 1-1 vein) in the Yamada ore zone (Fig. 2). The samples at Loc. 1 were collected from three different quartz druses filled with stibnite crystals in a crustiformbanded vein (Fig. 3). The morphological characteristics of the samples were examined both in hand specimen and in binocular microscope.

\section{Sulfur isotope analysis}

Analyzed stibnite crystals were separated by handpicking from seven samples, which are listed in Table 1, and were carefully checked for contamination via binocular microscope examination. A single or a few crystals were crushed and ground to powder for each analytical run.

All stibnite sulfur isotope measurements were conducted at the Geological Survey of Japan, using a conventional method: the stibnite was evolved to $\mathrm{H}_{2} \mathrm{~S}$ using tin (II)strong phosphoric acid (Kiba reagent) at $280^{\circ} \mathrm{C}$ (Sasaki et al., 1979), and precipitated as $\mathrm{Ag}_{2} \mathrm{~S}$ that was combusted to $\mathrm{SO}_{2}$ gas using $\mathrm{Cu}_{2} \mathrm{O}$ in a vacuum at $900^{\circ} \mathrm{C}$ (Robinson and Kusakabe, 1975). The gas was purified with a closed n-pentane trap (Kusakabe, 2005) to separate $\mathrm{SO}_{2}$ from $\mathrm{CO}_{2}$ due to contamination during sample preparation. The purified gas was analyzed on a Finnigan MAT 252 mass spectrometer, and the data are presented as $\delta^{34} \mathrm{~S}$

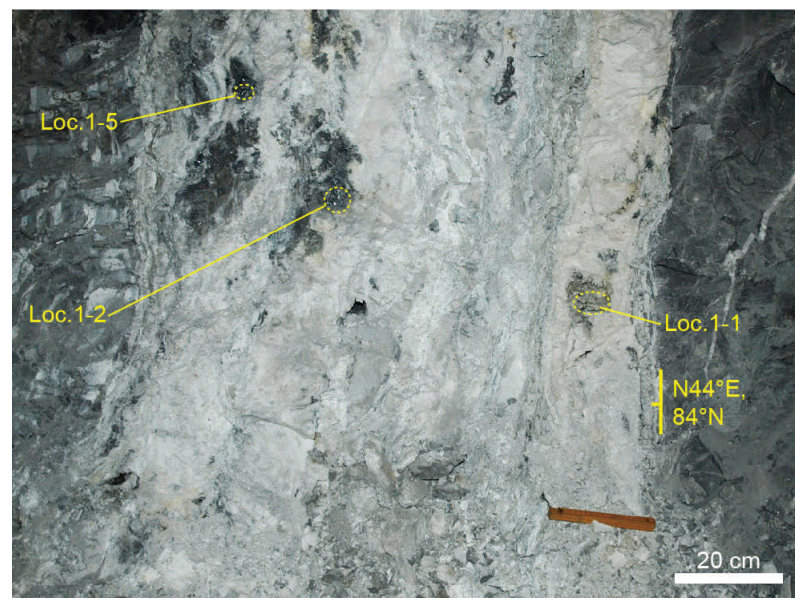

Fig. 3 A working face of the Shosen No. 2 vein at 10 ML, E45B looking towards the northeast (Loc. 1 in Fig. 2). Dotted circles on the vein indicate the area of druses where stibnite samples for sulfur isotopic measurements were collected. Loc. 1-1, Loc. 1-2 and Loc. 1-5 indicate the sample names that correspond to those in Table 1.

(\%o) relative to the Canyon Diablo Troilite (CDT). The overall experimental reproducibility in this study was $\pm 0.2 \%$ o $(1 \sigma)$.

\section{Results}

Mode of occurrence of stibnite

Morphological characteristics of stibnite at hand 
Table 1 Mode of occurrence and sulfur isotopic values for stibnite at the Hishikari deposit

\begin{tabular}{|c|c|c|c|c|}
\hline $\begin{array}{l}\text { Sampling } \\
\text { locations }\end{array}$ & Mode of occurrence of stibnite & Host rock & $\begin{array}{l}\delta^{34} S \\
(\%)\end{array}$ & Remarks \\
\hline $\begin{array}{l}\text { Loc. } 1 \text { (10 ML } \\
\text { E45B, Shosen No. } \\
2 \text { vein) }\end{array}$ & $\begin{array}{l}\text { Random growths of prismatic or acicular } \\
\text { stibnite on euhedral quartz crystals } \\
\text { forming a druse at Loc. } 1-1 \text { in Fig. } 3 \text {. } \\
\text { Some stibnite crystals are bent. Stibnite } \\
\text { crystals are } 10 \text { to } 23 \mathrm{~mm} \text { in size. }\end{array}$ & $\begin{array}{l}\text { Sedimentary } \\
\text { rocks } \\
\text { (Shimanto } \\
\text { Supergroup) }\end{array}$ & +0.6 & $\begin{array}{l}\text { Sample name: } \\
20120919 \\
\text { Loc. } 1-1\end{array}$ \\
\hline $\begin{array}{l}\text { Loc. } 1 \text { (10 ML } \\
\text { E45B, Shosen No. } \\
2 \text { vein })\end{array}$ & $\begin{array}{l}\text { Prismatic stibnite randomly growing } \\
\text { inwards from euhedral quartz cavity walls } \\
\text { at Loc. } 1-2 \text { in Fig. } 3 \text { (Fig. } 4 \mathrm{a} \text { ). } \\
\text { Stibnite crystals are } 1 \text { to } 15 \mathrm{~mm} \text { in size. }\end{array}$ & $\begin{array}{l}\text { Sedimentary } \\
\text { rocks } \\
\text { (Shimanto } \\
\text { Supergroup) }\end{array}$ & +0.7 & $\begin{array}{l}\text { Sample name: } \\
20120919 \\
\text { Loc. } 1-2\end{array}$ \\
\hline $\begin{array}{l}\text { Loc. } 1(10 \text { ML } \\
\text { E45B, Shosen No. } \\
2 \text { vein })\end{array}$ & $\begin{array}{l}\text { Aggregates of prismatic stibnite crystals, } \\
\text { randomly or radially growing on euhedral } \\
\text { quartz crystals, forming a druse at Loc. } \\
1-5 \text { in Fig. } 3 \text {. Stibnite crystals are } 1 \text { to } 12 \\
\text { mm in size. }\end{array}$ & $\begin{array}{l}\text { Sedimentary } \\
\text { rocks } \\
\text { (Shimanto } \\
\text { Supergroup) }\end{array}$ & +0.1 & $\begin{array}{l}\text { Sample name: } \\
20120919 \\
\text { Loc. } 1-5\end{array}$ \\
\hline $\begin{array}{l}\text { Loc. } 2 \text { (10 ML } \\
\text { E45B, Shosen No. } \\
5 \text { vein })\end{array}$ & $\begin{array}{l}\text { Aggregates of radial prismatic stibnite } \\
\text { crystals at Loc. } 2 \text { in Fig. } 2 \text { (Fig. } 4 \mathrm{~b} \text { ). } \\
\text { Stibnite crystals are } 4 \text { to } 30 \mathrm{~mm} \text { in size. }\end{array}$ & $\begin{array}{l}\text { Sedimentary } \\
\text { rocks } \\
\text { (Shimanto } \\
\text { Supergroup) }\end{array}$ & +0.4 & $\begin{array}{l}\text { A sample } \\
\text { provided by } \\
\text { Hishikari mine }\end{array}$ \\
\hline $\begin{array}{l}\text { Loc. } 3 \text { (40 ML } \\
\text { E18B, Shosen No. } \\
5 \text { vein })\end{array}$ & $\begin{array}{l}\text { Bundles of subparallel-orientation } \\
\text { prismatic stibnite crystals overgrown on } \\
\text { euhedral quartz crystals. Stibnite crystals } \\
\text { are } 1 \text { to } 6 \mathrm{~mm} \text { in size. }\end{array}$ & $\begin{array}{l}\text { Hishikari } \\
\text { Lower } \\
\text { Andesites }\end{array}$ & -0.2 & $\begin{array}{l}\text { Sample name: } \\
199407 \text { 3-3 }\end{array}$ \\
\hline $\begin{array}{l}\text { Loc. } 4 \quad(40 \quad \mathrm{ML} \\
\text { E21W, } \quad \text { Keisen } \\
\text { No.3 vein })\end{array}$ & $\begin{array}{l}\text { Aggregates of radial prismatic or acicular } \\
\text { stibnite crystals. Stibnite crystals are } 1 \text { to } \\
10 \mathrm{~mm} \text { in size. }\end{array}$ & $\begin{array}{l}\text { Hishikari } \\
\text { Lower } \\
\text { Andesites }\end{array}$ & -0.1 & $\begin{array}{l}\text { A sample } \\
\text { provided by } \\
\text { Hishikari mine }\end{array}$ \\
\hline $\begin{array}{lr}\text { Loc. } 5 & (40 \quad \text { ML } \\
\text { W83B, } & \text { Seisen } \\
\text { No.1-1) } & \end{array}$ & $\begin{array}{l}\text { Acicular or prismatic stibnite crystals. } \\
\text { The crystals are } 3 \text { to } 11 \mathrm{~mm} \text { in size. }\end{array}$ & $\begin{array}{l}\text { Hishikari } \\
\text { Lower } \\
\text { Andesites }\end{array}$ & +0.3 & $\begin{array}{l}\text { A sample } \\
\text { provided by } \\
\text { Hishikari mine }\end{array}$ \\
\hline
\end{tabular}

Note: Sampling locations correspond to those in Fig. 2.

specimen scale are summarized in Table 1. Stibnite commonly occurs as lead-gray prismatic or acicular crystals protruding randomly into a druse of quartz (Fig. $4 \mathrm{a}$ ), and/or as radiating aggregates (Fig. 4b). The crystals are elongated, up to $30 \mathrm{~mm}$ maximum (Table 1). There are no other ore minerals associated with stibnite at Loc. 1-1, 1-2 and 1-5, and Loc. 3 (Figs. 2 and 3). Whether other ore minerals coexist with stibnite is unknown for the samples from Locs. 2, 4 and 5 (Fig. 2).

\section{Sulfur isotopic data}

Seven $\delta^{34} \mathrm{~S}$ values for stibnite samples from Loc. 1 to 5 are listed in Table 1 . The values range between -0.2 and $+0.7 \%$ and are plotted in Fig. 5 , together with other sulfide data from previous studies. The $\delta^{34} \mathrm{~S}$ values of stibnite are consistent with one value of stibnite, $-0.2 \%$ reported by Imai et al. (2006).

\section{Discussion}

Formation of prismatic, acicular or radial stibnite crystals in quartz druses and fractures is a common mineralogical feature in many antimony-bearing hydrothermal deposits, indicating that stibnite precipitated during the last stage of sequential mineralization (e.g., Ikeda, 1969; Izawa et al., 1990; Bailly et al., 2000; Wagner and Cook, 2000; Wang et al., 2012). Although Izawa (1990) described stibnite as tending to form at higher elevations at the Hishikari deposit, the present study documents stibnite at 40 and $10 \mathrm{ML}$ at the Sanjin and Yamada ore zones, and indicates that stibnite mineralization overprinted the preceding $\mathrm{Au}-$ $\mathrm{Ag}$ mineralization responsible for forming the bonanza zone (150 to -50 ML, Fig. 1) (Ibaraki and Suzuki, 1993). The overprinting of stibnite mineralization on $\mathrm{Au}-\mathrm{Ag}$ mineralization has also been seen irrespective of depth at the Okuchi epithermal Au-Ag deposit near the Hishikari deposit (Fig. 1a; Ikeda, 1969). Stibnite, however, typically 


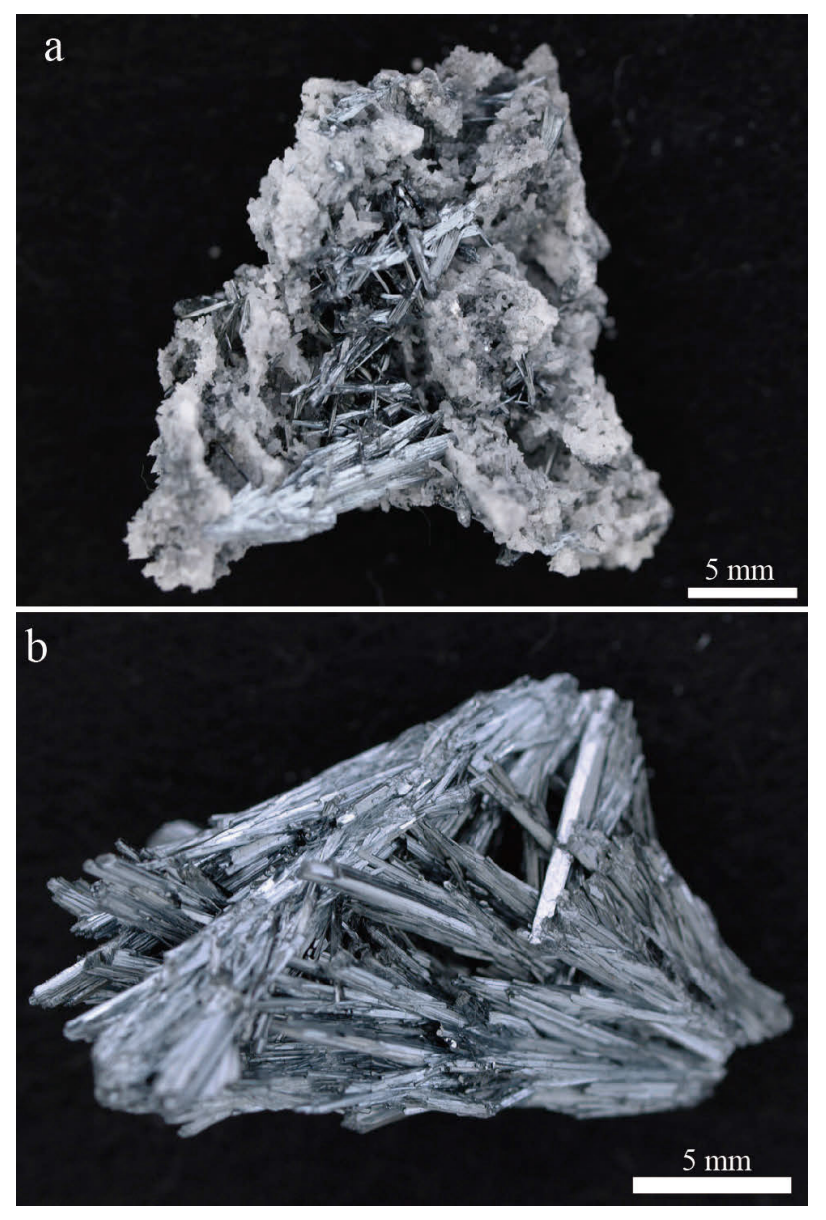

Fig. 4 Modes of occurrence of stibnite from the Shosen 5 vein, Sanjin ore zone. (a) Stibnite protruding into a druse of euhedral quartz (Loc. 1 in Fig. 2). (b) Aggregates of radially-distributed stibnite (Loc. 2 in Fig. 2).

preferentially precipitates in the peripheral portions of epithermal systems (Morteani et al., 2011; SchwarzSchampera, 2014), e.g., stibnite deposition on the top of an Au-Ag orebody near the surface (Kinoshita, 1973). This suggests that the overprinting of stibnite mineralization on Au-Ag mineralization at depth at the Hishikari and the Okuchi deposits may have required mineralogically unusual circumstances.

As shown in Fig. 5, the $\delta^{34} \mathrm{~S}$ values of stibnite form a narrow-range, -0.2 to $+0.7 \%$, representing different veins between 40 and 10 ML (Shosen No. 2 and No. 5 veins, and Keisen No. 3 vein in the Sanjin ore zone; and Seisen vein No. 1-1 vein in the Yamada ore zone) (Fig. 2). This suggests that the source of stibnite sulfur could be spatially homogeneous for these mine levels.

The $\delta^{34} \mathrm{~S}$ values of stibnite are also similar to previous study values for ginguro ( +0.4 and $+0.6 \%$ in Fig. 5$)$ and pyrite in veins and altered host rocks $(-1.1$ to $+1.8 \%$ in Fig. $5)$, although all $\delta^{34} \mathrm{~S}$ values from vein sulfides and altered rocks (Fig. 5) are higher than those of unaltered host rocks

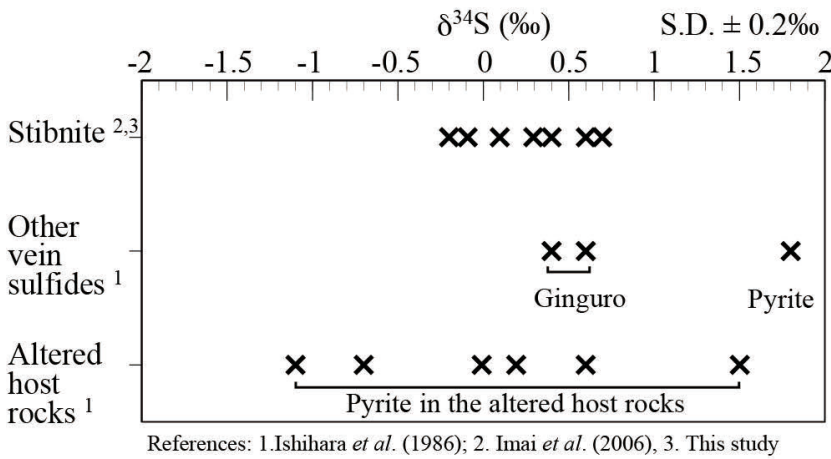

Fig. 5 Plot of sulfur isotopic values $\left(\delta^{34} S\right)$ for stibnite, other vein sulfides, and altered host rocks (Shimanto Supergroup sedimentary rocks) at the Hishikari deposit.

(Shimanto Supergroup sedimentary rocks), which range between -1.4 and $-21.5 \%$ and average $-12.0 \%$ (Ishihara et al., 1986). The similarity of $\delta^{34} \mathrm{~S}$ values between later stibnite mineralization and earlier ginguro mineralization suggests that the source of sulfide sulfur may have been the same throughout ore mineralization. The similarity of $\delta^{34} \mathrm{~S}$ values between stibnite and all other sulfides (ginguro and pyrite) indicates that the source of stibnite sulfur is the same as for the other sulfides; this sulfur source has been discussed in previous geological and isotopic studies, detailed as follows.

Ishihara et al. (1986) first proposed that sulfide sulfur at the Hishikari deposit was derived from magmatic fluid generated from a felsic subvolcanic intrusive body, ruling out the possibilities of other sources of sulfur based on interpretation of $\delta^{34} \mathrm{~S}$ data for sulfide sulfur in veins, altered host rocks, and unaltered host rocks (Shimanto Supergroup sedimentary rocks, Fig. 1). This study was followed by two more isotopic studies: Morishita (1993) discussed the low $\delta^{13} \mathrm{C}$ values $(\approx-11 \%$ ) of epithermal ore fluids in southern Kyushu, positing they may have been a result of contribution of organic carbon from the Shimanto Supergroup sedimentary rocks. Imai et al. (1998) proposed that the low $\delta \mathrm{D}$ values of ore fluids $(-60 \%$ o to $<-100 \%$ ) were a result of leaching of hydrogen from the Shimanto Supergroup sedimentary rocks. These two studies suggest that the Shimanto Supergroup sedimentary rocks are genetically related to ore fluids. With the interpretation of the $\delta^{13} \mathrm{C}$ and $\delta \mathrm{D}$ values referenced above, Shikazono (1999) reinterpreted the earlier $\delta^{34} \mathrm{~S}$ values of sulfides (Ishihara et al., 1986). Considering the Hishikari deposit was situated in the non-green tuff region where the Shimanto Supergroup sedimentary rocks underlay subaerial volcanic rocks (Fig. 1), Shikazono (1999) determined that the $\delta^{34} \mathrm{~S}$ values of sulfides at the Hishikari deposit $(-1.1$ to $+1.8 \%$ o in Fig. 5) were likely a result of a dominant contribution of magmatic sulfur, with a minor contribution of sedimentary sulfur from the Shimanto Supergroup sedimentary rocks. 


\section{Conclusions}

1. The overprinting of stibnite mineralization on $\mathrm{Au}-\mathrm{Ag}$ mineralization at the Hishikari deposit at depth may have been due to mineralogically unusual conditions.

2. The $\delta^{34} \mathrm{~S}$ values of stibnite, morphologically determined to be from the latest stage of sequential mineralization, are narrow-ranged $(-0.2$ to $+0.7 \%$ ) among different veins, suggesting that the source of stibnite sulfur could be spatially homogeneous at the Hishikari deposit.

3. The similarity of $\delta^{34} \mathrm{~S}$ values between stibnite, and ginguro from earlier mineralization suggests that the source of sulfide sulfur may have been the same throughout ore mineralization.

4. The similarity of $\delta^{34} \mathrm{~S}$ values among the stibnite, ginguro, and pyrite in veins and altered host rocks suggests a likely dominantly magmatic origin of stibnite sulfur, the same as for the other sulfides.

\section{Acknowledgements}

I am grateful to Mr. Morimoto, Mr. Takeuchi, and Mr. Yamato, from the Sumitomo Metal Mining Co., Ltd., Hishikari Mine, for their assistance with the underground survey, for providing stibnite samples, and for their beneficial discussions on stibnite mineralization. The original submission was significantly improved by constructive comments by the reviewer, Dr. Kenzo Sanematsu, the editorial committee members, Dr. Yutaka Takahashi and Dr. Takayuki Uchino, and the editor, Dr. Atsushi Suzuki.

\section{References}

Bailly, L., Bouchot, V., Beny, C. and Milesi, J. (2000) Fluid inclusion study of stibnite using infrared microscopy: An example from the Brouzils antimony deposit (Vendee, Armoriscan Massif, France). Economic Geology, 95, 221-226.

Gokçe A. and Spiro, B. (1991) Sulfur isotope study of source and deposits of stibnite in the Turhal Area, Turkey. Mineralium Deposita, 26, 30-33.

Ibaraki, K. (1990) General description of Yamada deposit, Hishikari mine. In Prof. Y. Urashima commemoration volume on the occasion of his retirement, 197-200.

Ibaraki, K. and Suzuki, R. (1993) Gold-silver quartzadularia veins of the Main, Yamada and Sanjin deposits, Hishikari gold mine; a comparative study of their geology and ore deposits. Resource Geology Special Issue, 14, 1-11.

Ikeda, T. (1969) On the ore deposits and prospecting at the Okuchi mine, Kagoshima prefecture. Mining Geology, 19, 132-146 (in Japanese with English abstract).

Imai, A., Shimazaki, H. and Nishizawa, T. (1998) Hydrogen isotope study of fluid inclusions in vein quartz, Hishikari gold deposits, Japan. Resource
Geology, 48, 159-170.

Imai, A., Shikazono, N., Shimizu, M. and Shimazaki, H. (2006) Sulfur isotopic study on $\mathrm{Hg}$ and Sb deposits in Japan. Resource Geology, 56, 37-48.

Ishihara, S., Sakamaki, Y., Sasaki, A., Teraoka, Y. and Terashima, S. (1986) Role of the basement in the genesis of the Hishikari gold-quartz vein deposit, southern Kyushu, Japan. Mining Geology, 36, 495-509.

Ishihara, S., Sasaki, A., Minagawa, T., Bunno, M., Shishido, A. and Tanaka, R. (2000) Paired sulfur isotopic belts: Late Cenozoic ore deposits of Southwest Japan. Bulletin of Geological Survey of Japan, 51, 283-297.

Izawa, E., Kurihara, M. and Itaya, T. (1993) K-Ar ages and initial Ar isotopic ratio of adularia-quartz veins from the Hishikari gold deposit, Japan. Resource Geology Special Issue, 14, 63-69.

Izawa, E., Urashima, Y., Ibaraki, K., Suzuki, R., Yokoyama, T., Kawasaki, K., Koga, A. and Taguchi, S. (1990) The Hishikari gold deposit: High grade epithermal veins in Quaternary volcanics of southern Kyushu, Japan. Journal of Geochemical exploration, 36, 1-56.

Kinoshita, K. (1973) Antimony ore, in Kinoshita, K., ed., Japanese Regional Ore Deposits Record: Japan, Asakura Publishing Co., Ltd., 210-220 (in Japanese).

Kusakabe, M. (2005) A closed pentane trap for separation of $\mathrm{SO}_{2}$ from $\mathrm{CO}_{2}$ for precise $\delta^{18} \mathrm{O}$ and $\delta^{34} \mathrm{~S}$ measurements. Geochemical Journal, 39, 285-287.

Matsuhisa, Y. and Aoki, M. (1994) Temperature and oxygen isotope variations during formation of the Hishikari epithermal gold-silver veins, southern Kyushu, Japan. Economic Geology, 89, 1608-1613.

Morishita, Y. (1993) Carbon and oxygen isotopic characteristics of epithermal veins in the Hokusatsu gold district, southern Kyushu, Japan. Resource Geology Special Issue, 14, 103-114.

Morteani, G., Ruggieri, G., Möller, P. and Preinfalk, C. (2011) Geothermal mineralized scale in the pipe system of the geothermal Piancastagnaio power plant (Mt. Amiata geothermal area): a key to understand the stibnite, cinnabarite and gold mineralization of Tuscany (central Italy). Mineralium Deposita, 46, 197-210.

Robinson, W. B. and Kusakabe, M. (1975) Quantitative preparation of sulfur dioxide ${ }^{34} \mathrm{~S} /{ }^{32} \mathrm{~S}$ analyses from sulfides by combustion with cuprous oxide. Analytical Chemistry, 47, 1179-1181.

Robinson, W. B. and Farrand, M. G. (1982) Sulfur isotopes and the origin of stibnite mineralization in New England, Australia. Mineralium Deposita, 17, 161-174.

Sanematsu, K., Duncan, R., Imai, A. and Watanabe, K. (2005) Geochronological constraints using ${ }^{40} \mathrm{Ar} /{ }^{39} \mathrm{Ar}$ dating on the mineralization of the Hishikari epithermal gold deposit, Japan. Resource Geology, 55, 249-266. 
Sasaki, A., Arikawa, Y. and Folinsbee, E. R. (1979) Kiba reagent method of sulfur extraction applied to isotopic work. Bulletin of Geological Survey of Japan, 30, 241-245.

Schwarz-Schampera, U. (2014) Antimony. In Gunn, G., ed., Critical Metals Handbook, UK, John Wiley \& Sons, Ltd., 70-98.

Sekine, R., Izawa, E. and Watanabe, K. (2002) Timing of fracture formation and duration of mineralization at the Hishikari deposit, southern Kyushu, Japan. Resource Geology, 52, 395-404.

Shikazono, N. (1999) Sulfur isotopic composition and origin of sulfide sulfur in epithermal Au-Ag vein-type deposits in Japan. Resource Geology Special Issue, 20, 39-45.

Shimizu, T. (2015) Elemental analysis of bonanza ores of the Ryosen veins, Hishikari epithermal $\mathrm{Au}-\mathrm{Ag}$ deposit, Japan, using micro X-ray fluorescence ( $\mu$-XRF). Bulletin of the Geological Survey of Japan, 66, $1-14$.

Sumitomo Metal Mining Co., Ltd. (2012) Hishikari mine. 10p. (in Japanese).
Tohma, Y., Imai, A., Sanematsu, K., Yonezu, K., Takahashi, R., Koyama, M., Sekine, R., Duncan, R. and Watanabe, K. (2010) Characteristics and mineralization age of the Fukusen No. 1 vein, Hishikari epithermal gold deposits, southern Kyushu, Japan. Resource Geology, 60, 348-358.

Wagner, T. and Cook, N. J. (2000) Late-Variscan antimony mineralization in the Rheinisches Schiefergebirge, NW Germany: evidence for stibnite precipitation by drastic cooling of high-temperature fluid systems. Mineralium Deposita, 35, 206-222.

Wang, J., Wen, H., Fan, H. and Zhu, J. (2012) Sm-Nd geochronology, REE geochemistry and $\mathrm{C}$ and $\mathrm{O}$ isotope characteristics of calcites and stibnites from the Banian antimony deposit, Guishou Province, China. Geochemical Journal, 46, 393-407.

Recieved November 30, 2016

Accepted January 18, 2017

\title{
菱刈浅熱水性金銀鉱床産輝安鉱の硫黄同位体比と産状
}

\author{
清水 徹
}

\section{要 旨}

菱刈浅熱水性金銀鉱床の輝安鉱産状の特徵と硫黄の起源を理解するため, 輝安鉱の産状と硫黄同位体比 $\left(\delta^{34} \mathrm{~S}\right)$ を精査した. 輝安鉱は角柱状または針状結晶を示して石英晶洞中に放射状の塊をなしており, 輝安鉱が一連の鉱化作用最末期に形成したこと を意味する.

輝安鉱試料は, ボナンザ (金に富む) ゾーン内の複数鉱脈の40若しくは10 ML (坑内深度レベル) にて採取した. 輝安鉱の硫黄 同位体比は, 狭い範囲：-0.2から $+0.7 \%$ (測定数：7）を示し, 輝安鉱の硫黄同位体比は過去の $\delta^{34} \mathrm{~S}$ 值： +0.4 から $+0.6 \%$ (銀黒)， 及び-1.1 から $+1.8 \%$ (脈内の黄鉄鉱, 及び四万十層群からなる熱水変質母岩) に類似している.

輝安鉱の鉱化作用がボナンザゾーン内に見られることは, 同一深度で輝安鉱の鉱化作用が金銀鉱化作用に重複していたことを 意味する. 輝安鉱が一般的に浅熱水環境の縁辺部, 例えば金銀鉱脈鉱床の地表に近い上部に形成することを考慮すると, 菱刈 鉱床では深部 (40及び10 ML) で輝安鉱と金銀鉱物が重複形成したことは, 鉱化作用としては特異な環境であったかもしれない.

狭い範囲を示す輝安鉱の $\delta^{34} S$ 值から, 輝安鉱硫黄の起源は空間的に均質であったと考えられる. 輝安鉱と銀黒の間の $\delta^{34} S$ 值の 類似性は, 鉱脈形成時, 硫化物硫黄の起源は時間的にも均質であったことを意味するかもしれない. また, 輝安鉱と他の全ての硫 化鉱物の $\delta^{34} S$ 值の類似性から, 輝安鉱硫黄の起源は, 従来研究に打ける他の硫化鉱物の起源に関する考察と同様に, 、グマが主 体であったと思われる. 
